\title{
Twenty Nine
}

National Cancer Institute

\section{Source}

National Cancer Institute. Twenty Nine. NCI Thesaurus. Code C105800.

A natural number greater than twenty-eight and less than thirty and the quantity that it denotes. 